\title{
Identification of Stripe Rust Resistance Genes in Common Wheat Cultivars From the Huang-Huai-Hai Region of China
}

\author{
Liang Huang, ${ }^{1,2}$ Xing Zhi Xiao, ${ }^{2}$ Bo Liu, ${ }^{2}$ Li Gao, ${ }^{2}$ Guo Shu Gong, ${ }^{1}$ Wan Quan Chen, ${ }^{2}$ Min Zhang, ${ }^{1, \dagger}$ and Tai Guo Liu ${ }^{2, \dagger}$ \\ ${ }^{1}$ College of Agronomy, Sichuan Agricultural University, Chengdu 611130, Sichuan Province, China \\ ${ }^{2}$ State Key Laboratory for Biology of Plant Diseases and Insect Pests, Institute of Plant Protection, Chinese Academy of Agri- \\ cultural Sciences, Beijing 100193, China
}

\begin{abstract}
Wheat stripe (yellow) rust, caused by Puccinia striiformis f. sp. tritici $(P s t)$, is a serious fungal disease worldwide, especially in the HuangHuai-Hai region, a main wheat production area in China. Gene postulation, molecular testing, and pedigree analysis were conducted to determine the presence of stripe rust resistance genes to 15 Pst races in 66 selected commercial wheat cultivars released from 2000 to 2016. In addition, races CYR32, CYR33, and CYR34 were used to evaluate resistance to $P s t$ at the adult-plant stage of wheat in the field.

was postulated in six cultivars. $\operatorname{Yr} 9$ was detected at a frequency of $28.8 \%$, and no cultivars carried $\mathrm{Yr} 5, \mathrm{Yr} 15$, or $\mathrm{Yr} 18$. Ten cultivars $(15.2 \%)$ exhibited adult-plant resistance in the field tests with three predominant races. Three cultivars (Langyan 43, Xinong 889, and Yunfeng 139) had all-stage resistance. These results are useful to growers selecting cultivars and to breeders aiming to use more resistance genes to develop new cultivars with effective resistance in order to reduce stripe rust damage.
\end{abstract} Four $Y r$ genes $(Y r 9, Y r 10, Y r 26$, and $Y r 32)$ were postulated in 24 wheat cultivars either singly or in combination. Thirty-six cultivars might contain unknown $\mathrm{Yr}$ genes, whereas no identified $\mathrm{Yr}$ gene
Keywords: adult-plant resistance, gene postulation, molecular marker test, wheat stripe rust, $\mathrm{Yr}$ gene
Wheat (Triticum aestivum L.) is the second most commonly grown food crop in China and is frequently affected by stripe rust, which is caused by Puccinia striiformis Westend. f. sp. tritici Erikss (Pst) (Wellings 2011). Destructive epidemics in 1950, 1964, 1990, 2002, and 2017 caused yield losses exceeding 6.0, 3.2, 1.8, 1.3, and 1.5 million metric tons, respectively, in China (Chen et al. 2009; Ma 2018; Wan et al. 2007). Severe outbreaks of wheat stripe rust occur as a result of susceptible cultivars, virulent races, and disease-favorable weather conditions (Chen et al. 2014). In 2009, a new Pst race virulent on wheat line G22 was detected in Sichuan Province, China (Liu et al. 2010). The G22 races were virulent to wheat cultivars with $\mathrm{Yr} 10$ and $\mathrm{Yr} 26$, among other stripe rust resistance $(Y r)$ genes and other resistant lines or cultivars such as the Guinong and 92R lines, Moro, and Chuanmai 42 (Liu et al. 2015). The frequency of the G22-virulent races has increased rapidly and spread to other regions of China ( $\mathrm{Li}$ et al. 2016; Liu et al. 2012; Wang et al. 2017), owing to the high infection fitness and aggressiveness of G22 on commercial wheat cultivars (Bai et al. 2018). Among G22 races, G22-9 (formerly V26) emerged as a new predominant race and was formally named race CYR34 (Bai et al. 2018; Liu et al. 2017). CYR34, CYR32, and CYR33 are currently the predominant races in China. Planting resistant cultivars is the most economic, effective, environmentally friendly, and easy-to-use method for controlling wheat stripe rust (Chen 2005). Therefore, developing wheat cultivars

${ }^{\dagger}$ Corresponding authors: M. Zhang; yalanmin@ 126.com, and T. G. Liu; tgliu@ippcaas.cn

Funding: This work was supported by grants from the National Natural Science Foundation of China (31871906, 31371884, and 31611130039), the Ministry of Science and Technology of the People's Republic of China (2018YFD0200500 and 2016YFD0300705), and the Ministry of Agriculture, China (CARS-03).

The author(s) declare no conflict of interest.

Accepted for publication 15 January 2020.

(C) 2020 The American Phytopathological Society with durable resistance is critical for sustainable control of this disease.

Adult-plant resistance (APR) and seedling resistance are two major types of resistance to stripe rust (Johnson and Taylor 1972). APR is expressed at the postseedling stage, and the level of resistance increases as the plant matures. Seedling resistance genes are expressed at all stages, which follow the gene-for-gene relationships (Flor 1971). This hypothesis states that interactions between a host and a specific pathogen depend on the presence of resistance genes in the host and the corresponding avirulence genes in the pathogen. The hypothesis provides the foundation for gene postulation. Dubin et al. (1989) proposed six steps of gene postulation for wheat resistance to stripe rust, which have been widely used in the wheat-Pst pathosystem (Feng et al. 2009; Li et al. 2006). By 2019, $82 Y r$ genes had been permanently named (Feng et al. 2018; Gessese et al. 2019; McIntosh et al. 2017; Nsabiyera et al. 2018; Pakeerathan et al. 2019), and some have been cloned and their linked molecular markers have been identified. These markers made it possible to improve the accuracy and reliability of gene postulation (Bai et al. 2010).

Wheat produced in the Huang-Huai-Hai region of China fulfills the food needs of more than 200 million people (Tang and $\mathrm{Li}$ 2012). In 2016, wheat was grown on 14.1 million hectares in these regions (58.3\% of the total wheat production area in China) and produced 87 million tons of grain $(67.5 \%)$. Stripe rust frequently causes big yield losses in the Huang-Huai-Hai region; therefore, there is an urgent need to control wheat stripe rust in this region. However, there is not enough information on $Y r$ genes in the released cultivars, which makes it difficult for growers in the region to choose a cultivar. Hence, the objective of this study was to identify $\mathrm{Yr}$ genes in 66 wheat cultivars that are widely grown in the Huang-Huai-Hai region of China. The evaluation of resistance in wheat cultivars to the predominant races of Pst at the adult-plant stage could also provide useful information for growers selecting cultivars to plant and for breeders aiming to use more effective genes to develop new wheat cultivars with adequate and durable resistance to stripe rust.

\section{Materials and Methods}

Plant material. Sixty-six wheat cultivars (Table 1) that were widely grown in the Huang-Huai-Hai region of China during 2000 
Table 1. Pedigrees of cultivars, stripe rust reactions at the adult-plant stage, and amplifications by $\operatorname{Yr}$ gene-specific molecular markers

\begin{tabular}{|c|c|c|c|c|c|c|c|c|c|c|c|c|c|}
\hline \multirow[b]{3}{*}{ Line } & \multirow[b]{3}{*}{ Cultivar } & \multirow[b]{3}{*}{ Pedigree } & \multirow{3}{*}{$\begin{array}{l}\text { Released } \\
\text { number }\end{array}$} & \multirow{2}{*}{\multicolumn{3}{|c|}{ Score at adult-plant stage $\mathrm{e}^{\mathrm{a}}$}} & \multicolumn{7}{|c|}{ Molecular marker test ${ }^{\mathbf{b}}$} \\
\hline & & & & & & & \multirow[b]{2}{*}{ Yr5 } & \multirow[b]{2}{*}{ Yr9 } & \multirow[b]{2}{*}{ Yr10 } & \multicolumn{2}{|c|}{ Yr15 } & \multirow[b]{2}{*}{ Yr18 } & \multirow[b]{2}{*}{ Yr26 } \\
\hline & & & & CYR32 & CYR33 & CYR34 & & & & KinI & $\overline{\text { KinII }}$ & & \\
\hline$\overline{1}$ & Gaoyou 9618 & $8515-4 / 8901-11-14$ & $\begin{array}{c}\text { Jishenmai } \\
2005007\end{array}$ & $10 \mathrm{R}$ & $40 \mathrm{~S}$ & OR & - & + & - & - & - & - & - \\
\hline 2 & Han 00-7086 & Han 93-4572/Tai 9115-3 & $\begin{array}{l}\text { Guoshenmai } \\
2007014\end{array}$ & $60 \mathrm{MS}$ & $40 \mathrm{MS}$ & $10 \mathrm{R}$ & - & + & - & - & - & - & - \\
\hline 3 & Heng 0628 & Heng 71-3/Han 6172 & $\begin{array}{l}\text { Jishenmai } \\
2008010\end{array}$ & $60 \mathrm{~S}$ & $40 \mathrm{~S}$ & 40MS & - & + & - & + & - & - & - \\
\hline 4 & Heng 6599 & 94-4277/Heng 4041 & $\begin{array}{l}\text { Jishenmai } \\
2006002\end{array}$ & $40 \mathrm{~S}$ & 40MS & $80 \mathrm{~S}$ & - & - & - & - & - & - & - \\
\hline 5 & Henong 6049 & Jimai 38/Henong 91459 & $\begin{array}{l}\text { Guoshenmai } \\
2009019\end{array}$ & 80MS & $60 \mathrm{~S}$ & $80 \mathrm{~S}$ & - & + & - & - & - & - & - \\
\hline 6 & Henong 827 & $\begin{array}{l}\text { Linyuan } 95-3091 / \mathrm{Shi} \\
4185\end{array}$ & $\begin{array}{l}\text { Jishenmai } \\
2008011\end{array}$ & $60 \mathrm{~S}$ & $60 \mathrm{~S}$ & $80 \mathrm{~S}$ & - & + & - & - & - & - & - \\
\hline 7 & Huaimai 16 & $\begin{array}{l}\text { Tal (Ms2) recurrent } \\
\text { selection }\end{array}$ & $\begin{array}{l}\text { Guoshenmai } \\
2001004\end{array}$ & $10 \mathrm{R}$ & $10 \mathrm{R}$ & 10MR & - & - & - & - & - & - & - \\
\hline 8 & Huaimai 18 & Yan 1064/Zhengzhou 891 & $\begin{array}{l}\text { Guoshenmai } \\
2001005\end{array}$ & $40 \mathrm{MS}$ & $20 \mathrm{MS}$ & $60 \mathrm{~S}$ & - & + & - & - & - & - & - \\
\hline 9 & Ji 5265 & Shi 4185/Ji 6023//9204 & $\begin{array}{l}\text { Guoshenmai } \\
2009016\end{array}$ & $80 \mathrm{~S}$ & $60 \mathrm{~S}$ & $100 \mathrm{~S}$ & - & + & - & - & - & - & - \\
\hline 10 & Jifeng 703 & Linfen 118/Shixin 163 & $\begin{array}{l}\text { Jishenmai } \\
2005001\end{array}$ & $60 \mathrm{~S}$ & $60 \mathrm{~S}$ & $10 \mathrm{R}$ & - & + & - & + & - & - & - \\
\hline 11 & Jimai 19 & Lumai 13/Linfen 5064 & $\begin{array}{l}\text { Guoshenmai } \\
2003014\end{array}$ & $30 \mathrm{~S}$ & 40MS & $20 \mathrm{MR}$ & - & - & - & - & - & - & - \\
\hline 12 & Jimai 21 & $\begin{array}{l}\text { 865186/Chuannongda } \\
84-1109 / / \mathrm{Ji} \text { 84-5418 }\end{array}$ & $\begin{array}{l}\text { Lunongshenzi } \\
{[2004] 022}\end{array}$ & $40 \mathrm{~S}$ & 40MS & $20 \mathrm{MR}$ & - & - & + & - & - & - & - \\
\hline 13 & Jining 16 & 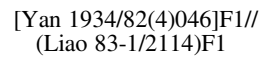 & $\begin{array}{l}\text { Lunongshenzi } \\
{[2004] 028}\end{array}$ & $40 \mathrm{MS}$ & $10 \mathrm{MS}$ & $0 \mathrm{R}$ & - & - & - & - & - & - & - \\
\hline 14 & Jining 17 & Laizhou 953/Shi 90-4005 & $\begin{array}{l}\text { Lunongshending } \\
{[2004] 029}\end{array}$ & $40 \mathrm{~S}$ & 40MS & $10 \mathrm{~S}$ & - & + & - & - & - & - & - \\
\hline 15 & Jinmai 1 & $\begin{array}{l}\text { Xiaoyan 22/ } \\
\text { Lankaoaizaoba }\end{array}$ & $\begin{array}{l}\text { Jishenmai } \\
2005009\end{array}$ & OR & $40 \mathrm{~S}$ & $10 \mathrm{MS}$ & - & + & - & - & - & - & - \\
\hline 16 & Kenong 199 & Shi $4185 \times$ Kenong 9204 & $\begin{array}{l}\text { Guoshenmai } \\
2006017\end{array}$ & $60 \mathrm{~S}$ & $40 \mathrm{~S}$ & $80 \mathrm{~S}$ & - & + & - & - & - & - & - \\
\hline 17 & Kexin 9 & $\underset{2-2}{\text { Yumai } 18-64 \text { lines/PH82- }}$ & $\begin{array}{l}\text { Lunongshen } \\
2009060\end{array}$ & $40 \mathrm{MS}$ & 40MS & 20MS & - & - & + & - & - & - & - \\
\hline 18 & Lai 95021 & $\begin{array}{l}\text { Jinan 13/Yanzhong 144// } \\
\text { wheat-Elytrigia } \\
\text { intermedia (Host) } \\
\text { Nevski./Yanzhong } 153\end{array}$ & $\begin{array}{l}\text { Lunongshenzi } \\
{[2001] 003}\end{array}$ & $60 \mathrm{MS}$ & $60 \mathrm{MS}$ & $60 \mathrm{~S}$ & - & - & - & - & - & - & - \\
\hline 19 & Langyan 43 & $\begin{array}{l}\text { 0591//Youmangbai 4/ } \\
\text { Lovrin 10//Aiganzao }\end{array}$ & $\begin{array}{l}\text { Jishenmai } \\
2005013\end{array}$ & OR & OR & $0 \mathrm{R}$ & - & + & - & - & - & - & - \\
\hline 20 & Liangxing 99 & $\begin{array}{l}\text { Ji 91102/Lumai 14// } \\
\text { PH85-16 }\end{array}$ & $\begin{array}{l}\text { Guoshenmai } \\
2006016\end{array}$ & $40 \mathrm{~S}$ & $5 \mathrm{R}$ & $0 \mathrm{R}$ & - & - & - & - & - & - & - \\
\hline 21 & Linmai 4 & Lumai 23/Lin 9015 & $\begin{array}{l}\text { Lunongshen } \\
2006046\end{array}$ & $60 \mathrm{~S}$ & $60 \mathrm{~S}$ & $40 \mathrm{~S}$ & - & - & + & - & - & - & - \\
\hline 22 & Luohan 6 & Yumai 49/Shannong 45 & $\begin{array}{l}\text { Guoshenmai } \\
2006020\end{array}$ & $10 \mathrm{~S}$ & $60 \mathrm{~S}$ & $60 \mathrm{~S}$ & - & - & - & - & - & - & - \\
\hline 23 & Luohan 8 & Wenmai 6/Yumai 48 & $\begin{array}{l}\text { Yushenmai } \\
2008013\end{array}$ & OR & $40 \mathrm{~S}$ & $40 \mathrm{~S}$ & - & - & - & - & - & - & - \\
\hline 24 & Qifeng 1 & $\begin{array}{l}\text { Chang 95-8//Aurora/ } \\
\text { Mentana/ } \\
\text { (Baihuomai+Baiyupi+ } \\
\text { Xiaobaimai)// } \\
\text { Xiannong } \\
\text { 39///Xinong 64/Yanda } \\
\text { 24/Yannong 14 }\end{array}$ & $\begin{array}{l}\text { Lunongshen } \\
2009056\end{array}$ & $60 \mathrm{~S}$ & $40 \mathrm{MS}$ & $40 \mathrm{~S}$ & - & + & - & - & - & - & - \\
\hline 25 & Qingnong 2 & $\begin{array}{l}\text { Lumai 14/Yannong 15/ } \\
\text { Aiganmai }\end{array}$ & $\begin{array}{l}\text { Lunongshen } \\
2010070\end{array}$ & $10 \mathrm{R}$ & $40 \mathrm{MS}$ & $10 \mathrm{R}$ & - & - & + & - & - & - & - \\
\hline 26 & Shannong 12 & 828006/PH85-4 & $\begin{array}{r}\text { Lushenmai } \\
2005045\end{array}$ & $40 \mathrm{MS}$ & $40 \mathrm{MS}$ & $10 \mathrm{MS}$ & - & - & - & - & - & - & - \\
\hline 27 & Shannong 15 & Jinan 17/Jihe 916 & $\begin{array}{l}\text { Lunongshen } \\
2006057\end{array}$ & 40MS & $40 \mathrm{~S}$ & $40 \mathrm{~S}$ & - & - & - & - & - & - & - \\
\hline 28 & Shannong 17 & L156/Laizhou 137 & $\begin{array}{l}\text { Guoshenmai } \\
2009015\end{array}$ & $60 \mathrm{~S}$ & $80 \mathrm{~S}$ & $40 \mathrm{~S}$ & - & - & - & - & - & - & - \\
\hline 29 & Shannong 18 & L156/Laizhou 137 & $\begin{array}{l}\text { Guoshenmai } \\
2009015\end{array}$ & $40 \mathrm{~S}$ & 30MS & $20 \mathrm{MS}$ & - & - & - & - & - & - & - \\
\hline 30 & Shannong 21 & Laizhou 137/Yanfu 188 & $\begin{array}{l}\text { Lunongshen } \\
20100071\end{array}$ & $1 \mathrm{R}$ & $10 \mathrm{R}$ & $5 \mathrm{R}$ & - & + & - & - & - & - & - \\
\hline 31 & Shannong 23 & $\begin{array}{l}\text { Tal (Ms2) recurrent } \\
\text { selection }\end{array}$ & $\begin{array}{l}\text { Lunongshen } \\
2011034\end{array}$ & $60 \mathrm{~S}$ & $40 \mathrm{~S}$ & $40 \mathrm{~S}$ & - & + & - & + & - & - & - \\
\hline 32 & Shannong 29 & Linmai 6/J1781 & $\begin{array}{l}\text { Guoshenmai } \\
2016024\end{array}$ & $60 \mathrm{~S}$ & $60 \mathrm{~S}$ & $80 \mathrm{~S}$ & - & - & - & - & - & - & - \\
\hline 33 & Shannong 664 & 520627/Nannong 871 & $\begin{array}{c}\text { Lunongshenzi } \\
{[2002] 022}\end{array}$ & $40 \mathrm{MS}$ & $0.5 \mathrm{MR}$ & $10 \mathrm{MR}$ & - & + & - & + & - & - & - \\
\hline 34 & Shannongzimai 1 & $\begin{array}{l}\text { The total DNA of the } \\
\text { Honggaoliang was } \\
\text { introduced into the Jihe } \\
916 \text { through the pollen } \\
\text { tube channel }\end{array}$ & $\begin{array}{l}\text { Lunongshen } \\
2010072\end{array}$ & 40MS & 40MS & $10 \mathrm{R}$ & - & - & - & - & - & - & - \\
\hline
\end{tabular}

\footnotetext{
a Values indicate percent severity. $\mathrm{R}=$ resistant, $\mathrm{S}=$ susceptible, $\mathrm{MS}=$ moderately susceptible, and $\mathrm{MR}=$ moderately resistant.

$\mathrm{b}+=$ positive amplification by PCR; $-=$ negative amplification by PCR.
} 
Table 1. (Continued from previous page)

\begin{tabular}{|c|c|c|c|c|c|c|c|c|c|c|c|c|c|}
\hline \multirow[b]{3}{*}{ Line } & \multirow[b]{3}{*}{ Cultivar } & \multirow[b]{3}{*}{ Pedigree } & \multirow{3}{*}{$\begin{array}{l}\text { Released } \\
\text { number }\end{array}$} & \multirow{2}{*}{\multicolumn{3}{|c|}{ Score at adult-plant stage ${ }^{a}$}} & \multicolumn{7}{|c|}{ Molecular marker test ${ }^{\mathbf{b}}$} \\
\hline & & & & & & & \multirow[b]{2}{*}{ Yr5 } & \multirow[b]{2}{*}{$\operatorname{Yr} 9$} & \multirow[b]{2}{*}{ Yr10 } & \multicolumn{2}{|c|}{ Yr15 } & \multirow[b]{2}{*}{ Yr18 } & \multirow[b]{2}{*}{ Yr26 } \\
\hline & & & & $\overline{\text { CYR32 }}$ & CYR33 & $\overline{\text { CYR34 }}$ & & & & KinI & KinII & & \\
\hline$\overline{35}$ & Shanrong 3 & $\begin{array}{l}\text { Jinan 177, Thinopyrum } \\
\text { elongatum and } \\
\text { Agropyron elongatum } \\
\text { somatic cell fusion }\end{array}$ & $\begin{array}{l}\text { Lunongshenzi } \\
{[2004] 030}\end{array}$ & $60 \mathrm{~S}$ & $60 \mathrm{~S}$ & $60 \mathrm{~S}$ & - & + & - & + & - & - & - \\
\hline 36 & Shi 4185 & $\begin{array}{l}\text { Tal/Zhi 8094//Yumai 2/3/ } \\
\text { Jimai 26(Aiganzao/ } \\
\text { Lovrin 10//Jinfeng 1) }\end{array}$ & $\begin{array}{l}\text { Guoshenmai } \\
2006017\end{array}$ & $80 \mathrm{~S}$ & $40 \mathrm{~S}$ & $80 \mathrm{~S}$ & - & + & - & - & - & - & - \\
\hline 37 & Shijiazhuang 8 & $\begin{array}{l}\text { Shi 91-5096//Shi } \\
\text { 9306(GS Jimai 38) }\end{array}$ & $\begin{array}{l}\text { Jishenmai } \\
2007011\end{array}$ & $60 \mathrm{MS}$ & $40 \mathrm{MS}$ & $10 \mathrm{MS}$ & - & + & - & - & - & - & - \\
\hline 38 & Shimai 15 & $\begin{array}{l}\text { (GS Jimai 38/92R137)/ } \\
\text { GS Jimai } 38\end{array}$ & $\begin{array}{l}\text { Guoshenmai } \\
2009025\end{array}$ & $60 \mathrm{~S}$ & $60 \mathrm{MS}$ & $20 \mathrm{MS}$ & - & + & - & - & - & - & - \\
\hline 39 & Shimai 16 & Yumai 31/Shi 96-4495 & $\begin{array}{l}\text { Jishenmai } \\
2005002\end{array}$ & $60 \mathrm{MS}$ & $60 \mathrm{MS}$ & $60 \mathrm{MS}$ & - & + & - & - & - & - & - \\
\hline 40 & Shimai 18 & $\begin{array}{l}\text { Shi 4185/(92 Jian 3/T447) } \\
\text { F2 superior individual }\end{array}$ & $\begin{array}{l}\text { Jishenmai } \\
2008004\end{array}$ & $60 \mathrm{~S}$ & $80 \mathrm{~S}$ & $100 \mathrm{~S}$ & - & + & - & - & - & - & - \\
\hline 41 & Shixin 616 & $\begin{array}{l}\text { Damuzhiai///6069/Jinfeng } \\
1 / / / 9831\end{array}$ & $\begin{array}{l}\text { Jishenmai } \\
2008001\end{array}$ & $60 \mathrm{~S}$ & $80 \mathrm{~S}$ & $80 \mathrm{~S}$ & - & + & - & - & - & - & - \\
\hline 42 & Shixin 618 & $4512 / 523 / 735-10$ & $\begin{array}{l}\text { Jishenmai } \\
2008001\end{array}$ & $80 \mathrm{~S}$ & $60 \mathrm{~S}$ & 20MS & - & + & - & - & - & - & - \\
\hline 43 & Shixin 828 & 422/Shixin 163//612 & $\begin{array}{l}\text { Jishenmai } \\
2013012\end{array}$ & 40MS & 40MS & 20MS & - & - & + & - & - & - & - \\
\hline 44 & Shiyou 17 & Ji 935-352/Lumai 21 & $\begin{array}{l}\text { Jishenmai } \\
2007007\end{array}$ & $40 \mathrm{~S}$ & $60 \mathrm{~S}$ & $40 \mathrm{~S}$ & - & - & + & - & - & - & - \\
\hline 45 & Taishan 21 & $\begin{array}{l}\text { 26744/Taishan 10// } \\
\text { Lovinin 10/Weier/ } \\
\text { Ruluo/Youbaomai/3/ } \\
\text { Lumai } 18\end{array}$ & $\begin{array}{l}\text { Guoshenmai } \\
2003015\end{array}$ & $10 \mathrm{MR}$ & $5 \mathrm{MR}$ & $5 \mathrm{R}$ & - & - & + & - & - & - & - \\
\hline 46 & Taishan 22 & Lumai 18/Lumai 14 & $\begin{array}{l}\text { Guoshenmai } \\
2004013\end{array}$ & $0 \mathrm{R}$ & $10 \mathrm{R}$ & $20 \mathrm{MR}$ & - & - & + & - & - & - & - \\
\hline 47 & Taishan 24 & 904017/Zhengzhou 8329 & $\begin{array}{l}\text { Lushenmai } \\
{[2005] 044}\end{array}$ & 20MR & $10 \mathrm{R}$ & $5 \mathrm{MR}$ & - & - & - & - & - & - & - \\
\hline 48 & Tanmai 98 & Jining 13/942 & $\begin{array}{l}\text { Guoshenmai } \\
2010011\end{array}$ & $60 \mathrm{~S}$ & 40MS & $5 \mathrm{R}$ & - & - & - & - & - & - & - \\
\hline 49 & Weimai 7 & $\begin{array}{l}\text { Linfeng 550/Qianni/ } \\
\text { Zhongyin } 2\end{array}$ & $\begin{array}{l}\text { Lunongshenzi } \\
{[2001] 032}\end{array}$ & $40 \mathrm{~S}$ & 40MS & $40 \mathrm{MS}$ & - & + & - & - & - & - & - \\
\hline 50 & Weimai 8 & 88-3149/Aus621108 & $\begin{array}{l}\text { Lunongshenzi } \\
{[2003] 028}\end{array}$ & 40MS & 40MS & $20 \mathrm{MR}$ & - & + & - & + & - & - & - \\
\hline 51 & Wennong 5 & Lumai 21/Taishan 5 & $\begin{array}{l}\text { Lunongshenzi } \\
{[2003] 031}\end{array}$ & $40 \mathrm{MS}$ & $40 \mathrm{MS}$ & $20 \mathrm{MR}$ & - & - & - & - & - & - & - \\
\hline 52 & Wennong 6 & $\begin{array}{l}\text { 915021//Lumai 18/ } \\
876161\end{array}$ & $\begin{array}{l}\text { Lunongshen } \\
2006056\end{array}$ & $40 \mathrm{~S}$ & 30MS & $5 \mathrm{R}$ & - & - & - & - & - & - & - \\
\hline 53 & Xiaoyan 22 & $\begin{array}{l}\text { Xiaoyan 6//775-1/ } \\
\text { Xiaoyan } 107\end{array}$ & $\begin{array}{l}\text { Guoshenmai } \\
2003034\end{array}$ & $30 \mathrm{~S}$ & $40 \mathrm{MS}$ & $40 \mathrm{~S}$ & - & + & - & - & - & - & - \\
\hline 54 & Xiaoyan 81 & Xiaoyan 54/8602 & $\begin{array}{l}\text { Jishenmai } \\
2005006\end{array}$ & $20 \mathrm{MR}$ & 40MS & $0 \mathrm{R}$ & - & - & + & - & - & - & - \\
\hline 55 & Xin 2899 & $\begin{array}{l}\text { [Lovrin 13×71(17)6-1]/ } \\
\text { Laiyang 584/Linfen } \\
\text { 5064/Lumai } 14\end{array}$ & $\begin{array}{l}\text { Lunongshen } \\
2009059\end{array}$ & $80 \mathrm{~S}$ & $60 \mathrm{MS}$ & $40 \mathrm{MS}$ & - & + & - & - & - & - & - \\
\hline 56 & Xinong 889 & $\begin{array}{l}\text { Xiaoyan 6/Xiaoyan 8335- } \\
\text { 2//E Han-4 }\end{array}$ & $\begin{array}{l}\text { Yuyinmai } \\
2006005\end{array}$ & $0 \mathrm{R}$ & $0 \mathrm{R}$ & OR & - & - & + & - & - & - & - \\
\hline 57 & Yan 99102 & $\begin{array}{l}\text { (Yanhangxuan 2/Lin } \\
9511) \mathrm{F} 1 / / \mathrm{Y} \text { an BLU } \\
14-15\end{array}$ & $\begin{array}{l}\text { Guoshenmai } \\
2016012\end{array}$ & $60 \mathrm{~S}$ & $60 \mathrm{~S}$ & $40 \mathrm{~S}$ & - & - & - & - & - & - & - \\
\hline 58 & Yannong 0428 & Yan 1668/Lumai 21 & $\begin{array}{l}\text { Lunongshen } \\
2008058\end{array}$ & $40 \mathrm{~S}$ & 20MR & $10 \mathrm{R}$ & - & - & - & - & - & - & - \\
\hline 59 & Yannong 19 & Yan 1933/Shaan 82-29 & $\begin{array}{l}\text { Lunongshenzi } \\
{[2001] 001}\end{array}$ & $60 \mathrm{~S}$ & 40MS & $10 \mathrm{R}$ & - & - & - & - & - & - & - \\
\hline 60 & Yannong 21 & Yan 1933/Shaan 82-29 & $\begin{array}{l}\text { Guoshenmai } \\
2004016\end{array}$ & $40 \mathrm{~S}$ & $60 \mathrm{MS}$ & $40 \mathrm{MS}$ & - & - & - & - & - & - & - \\
\hline 61 & Yannong 22 & $\begin{array}{l}\text { Lumai } 14 / / \mathrm{Yu} 132 / \\
\text { "87chu } 20 "\end{array}$ & $\begin{array}{l}\text { Lunongshenzi } \\
\text { [2002]024 }\end{array}$ & $40 \mathrm{~S}$ & $40 \mathrm{~S}$ & $20 \mathrm{MS}$ & - & + & - & - & - & - & - \\
\hline 62 & Yannong 836 & $\begin{array}{l}\text { Shannong 721511/// } \\
\text { Predgornaya/Anhui 9/ } \\
\text { Hongkeouroubai/ } \\
\text { Bainimo 62///Yumai } \\
\text { 54(space breeding) }\end{array}$ & $\begin{array}{l}\text { Lunongshen } \\
2010073\end{array}$ & $40 \mathrm{~S}$ & 40MS & $1 \mathrm{R}$ & - & - & - & - & - & - & - \\
\hline 63 & Yunfeng 139 & $\begin{array}{l}\text { Xiaoyan 22/6/[Triticum } \\
\text { turgidum L. var. } \\
\text { dicoccoides (Koern.) } \\
\text { Bowd AS846// } \\
\text { Shaanmai 8003/ } \\
\text { Shanmai 8007)F4/3/ } \\
\text { Shaan 229/4/Aiganzao] } \\
\text { F3/5/N9134 }\end{array}$ & $\begin{array}{l}\text { Wanmai } \\
2011006\end{array}$ & $0 \mathrm{R}$ & $0 \mathrm{R}$ & $5 \mathrm{R}$ & - & - & + & - & - & - & + \\
\hline 64 & Zhouheimai 1 & Zhoumai 9/Luozhen 1 & $\begin{array}{c}\text { Yushenmai } \\
2011013\end{array}$ & 40MS & $10 \mathrm{R}$ & $10 \mathrm{R}$ & - & + & - & - & - & - & - \\
\hline 65 & Zhoumai 24 & $\begin{array}{l}\text { Bainong 791/65(14)3/ } \\
\text { Kanghuihong////Aifeng } \\
\text { 3//Mengxian 201/ } \\
\text { Neuzuch/Yanshi 4//I } \\
\text { Zhou 8425B//II } \\
\text { Xiaoyan 6/NS2761 }\end{array}$ & $\begin{array}{r}\text { Yushenmai } \\
2009002\end{array}$ & $1 \mathrm{R}$ & $10 \mathrm{MR}$ & OR & - & + & - & - & - & - & - \\
\hline 66 & $\mathrm{Zi} 12$ & $\begin{array}{l}\text { 73-110Yexuan 1//03201/ } \\
\text { 3/73-1104/Yexuan 1/4/ } \\
\text { Guinong 35-2 }\end{array}$ & $\begin{array}{l}\text { Lunongshenzi } \\
{[2001] 030}\end{array}$ & $5 \mathrm{R}$ & $1 \mathrm{MR}$ & $20 \mathrm{MR}$ & - & - & + & - & - & - & - \\
\hline
\end{tabular}


to 2016 were used in this study. Twenty-one near-isogenic lines (NILs) with the Avocet S background and susceptible variety Mingxian 169 (Table 2) were also included in the study as $\mathrm{Yr}$ gene references and a susceptible check, respectively. These seeds were provided by the State Key Laboratory for Biology of Plant Diseases and Insect Pests (SKLBPI) at the Institute of Plant Protection, Chinese Academy of Agricultural Sciences (IPPCAAS).

Pst races. Fifteen Pst races (Table 2), including seven from China (66E26, 72E66, 70E10, 63E254, 111E239, 111E222, and 127E255) and eight from Europe (66E74 [DK], 98E26 [DK], 66E10 [DK], $66 \mathrm{E} 154[\mathrm{DK}], 86 \mathrm{E} 90$ [UK], 70E72 [DK], 114E26 [DK], and 98E90 [DK]), were propagated and multiplied at SKLBPI and IPPCAAS from single uredinia.

Seedling tests. The 15 Pst races were used to inoculate the wheat cultivars, $Y r$ gene NILs, and the susceptible check. Thirty cultivars with six to eight seeds for each cultivar were planted in a plastic box $(20 \times 30 \times 10 \mathrm{~cm})$ filled with soil mixture, and the boxes were placed in a greenhouse. Seedlings were inoculated by spraying a suspension of $10 \mathrm{mg}$ of fresh urediniospores in $1 \mathrm{ml}$ of Isopar L lightweight mineral oil (ExxonMobil Chemical Co. Ltd., Irving, TX) using an atomizer pressured by an air pump $(20 \mathrm{kPa})$ when the seedlings were $10 \mathrm{~cm}$ high, approximately 7 days after sowing (Liu et al. 2015). After the mineral oil evaporated, the plants were placed in a sealed barrel to maintain moisture and held at $10^{\circ} \mathrm{C}$ for a day in the dark and then transferred to the greenhouse at 14 to $18^{\circ} \mathrm{C}$ with $16 \mathrm{~h}$ of light each day. Approximately 15 days after inoculation when rust was fully developed on Mingxian 169 and Avocet S, the infection types (ITs) were recorded based on a 0 to 9 scale (Line and Qayoum 1992). Plants with IT 0 to 6 were considered resistant, whereas those with IT 7 to 9 were considered susceptible.

Molecular marker tests. Genomic DNA from $10 \mathrm{mg}$ of leaves of each cultivar was extracted using the cetyltrimethylammonium bromide method. The DNA concentration was measured with an ND-1000 NanoDrop spectrophotometer (Thermo Fisher Scientific, Waltham, MA) and diluted to $100 \mathrm{ng} / \mu \mathrm{l}$ with $\mathrm{ddH}_{2} \mathrm{O}$. Seven molecular markers (Tables 3 and 4) linked to $\operatorname{Yr} 5$ (Yr5-KASP) (Marchal et al. 2018), Yr9 (AF1/4) (Francis et al. 1995), Yr10 (SC200) (Shao et al. 2001),
Yr15 (KinI and KinII) (Klymiuk et al. 2018), Yr18 (csLV34) (Lagudah et al. 2006), and Yr26 (We173) (Wang et al. 2008) were used to test all cultivars. The PCRs were performed in a $25-\mu 1$ reaction mixture containing $12.5 \mu \mathrm{l}$ of EasyTaq PCR SuperMix (TransGen Biotech, Beijing, China), $1 \mu \mathrm{l}(10 \mathrm{ng} / \mu \mathrm{l})$ of each forward and reverse primer, $1 \mu \mathrm{l}$ $(100 \mathrm{ng} / \mu \mathrm{l})$ of template DNA, and $9.5 \mu \mathrm{l}$ of $\mathrm{ddH}_{2} \mathrm{O}$. The PCR products were separated on a $2.0 \%$ agarose gel, and images were taken under a WSE-5200 integrated gel imaging system (Atto Corporation, Tokyo, Japan).

Field tests. The 66 wheat cultivars were evaluated for stripe rust reactions after inoculation separately with races CYR32, CYR33, and CYR34 in field nurseries at the Langfang Station, Hebei Province. In early October, seeds $(5 \mathrm{~g})$ of each cultivar were sown in a single row ( $1 \mathrm{~m}$ length and $0.33 \mathrm{~m}$ between rows). Susceptible cultivar Mingxian 169 was planted between each of the 20 tested wheat cultivars and perpendicular to the nursery to aid the spread of spores. Each nursery was surrounded by a barrier of winter wheat to minimize the unintentional spread of spores (Hovmøller 2007). Mingxian 169 plants were inoculated by spraying a suspension of $1 \mathrm{~g}$ of fresh urediniospores in $300 \mathrm{ml}$ of Isopar L lightweight mineral oil in midApril when the plants were in the jointing stage. After the oil evaporated for 1 to $2 \mathrm{~h}$, the plants were sprayed with 1:2,000 Tween 20 and water solution and covered with plastic overnight to maintain moisture in the spreader rows. Irrigation was applied every 10 days to maintain moisture in order to promote stripe rust development. Stripe rust IT and severity were recorded twice in late May and early June using the method of Chen et al. (2007) when the plants were in the milk stage and Mingxian 169 was completely infected. Disease severity was assessed visually using the percentage of diseased leaf area covered by stripe rust.

Data analysis. Gene postulations were carried out based on the method of Dubin et al. (1989). SAS 9.1.3 software (Statistical Analysis Systems, Cary, NC) was used for statistical analysis (Wamishe and Milus 2004; Wamishe et al. 2004). According to the gene-for-gene hypothesis, cultivars that have high ITs (susceptible) to a specific race cannot have a $\mathrm{Yr}$ gene to which the race produces a low IT (avirulent). For each cultivar, the first step of the program was to summarize the

Table 2. Infection types of $21 \mathrm{Yr}$ near-isogenic lines inoculated with 15 races of Puccinia striiformis $\mathrm{f}$. sp. tritici

\begin{tabular}{|c|c|c|c|c|c|c|c|c|c|c|c|c|c|c|c|}
\hline \multirow[b]{2}{*}{ Cultivar ${ }^{\mathbf{a}}$} & \multicolumn{15}{|c|}{ Infection type $^{b}$} \\
\hline & $\overline{66 E 74}$ & 98E26 & $66 \mathrm{E} 10$ & $66 \mathrm{E} 154$ & $86 \mathrm{E90}$ & 70E72 & 114E26 & 98E90 & $66 \mathrm{E} 26$ & $72 \mathrm{E} 66$ & $70 \mathrm{E} 10$ & $127 \mathrm{E} 255$ & 63E254 & 111E239 & 111E222 \\
\hline $\mathrm{AvS} / Y r 1$ & 1 & 1 & 2 & 5 & 2 & 3 & 1 & 2 & 1 & 1 & 1 & 7 & 7 & 7 & 7 \\
\hline $\mathrm{AvS} / Y r 3$ & 7 & 6 & 7 & 7 & 7 & 7 & 7 & 7 & 7 & 3 & 7 & 7 & 7 & 7 & 7 \\
\hline $\mathrm{AvS} / Y r 4$ & 7 & 7 & 7 & 7 & 7 & 7 & 7 & 7 & 7 & 7 & 7 & 8 & 4 & 7 & 7 \\
\hline $\mathrm{AvS} / Y r 5$ & 2 & 1 & 1 & 0 & 1 & 2 & 1 & 1 & 1 & 0 & 0 & 2 & 0 & 0 & 1 \\
\hline AvS/Yr6 & 7 & 7 & 7 & 7 & 5 & 3 & 7 & 7 & 7 & 7 & 7 & 7 & 7 & 7 & 7 \\
\hline $\mathrm{AvS} / Y r 7$ & 7 & 7 & 7 & 7 & 7 & 4 & 8 & 7 & 7 & 7 & 7 & 7 & 7 & 7 & 7 \\
\hline AvS/Yr8 & 7 & 7 & 6 & 7 & 7 & 4 & 7 & 7 & 7 & 5 & 7 & 8 & 7 & 7 & 7 \\
\hline $\mathrm{AvS} / Y r 9$ & 3 & 1 & 3 & 5 & 0 & 1 & 3 & 0 & 1 & 0 & 1 & 7 & 7 & 7 & 7 \\
\hline $\mathrm{AvS} / \mathrm{Yr} 10$ & 3 & 2 & 0 & 0 & 1 & 1 & 7 & 1 & 1 & 1 & 1 & 7 & 7 & 4 & 4 \\
\hline $\mathrm{AvS} / \mathrm{Yr} 15$ & 2 & 1 & 1 & 5 & 0 & 7 & 4 & 1 & 2 & 1 & 2 & 0 & 0 & 2 & 0 \\
\hline $\mathrm{AvS} / \mathrm{Yr} 17$ & 1 & 7 & 7 & 7 & 5 & 7 & 2 & 6 & 5 & 4 & 7 & 7 & 7 & 7 & 7 \\
\hline $\mathrm{AvS} / \mathrm{Yr} 24$ & 3 & 3 & 7 & 2 & 5 & 1 & 2 & 2 & 1 & 2 & 2 & 7 & 7 & 4 & 4 \\
\hline AvS/Yr25 & 3 & 6 & 2 & 1 & 1 & 1 & 7 & 7 & 4 & 1 & 3 & 7 & 7 & 7 & 7 \\
\hline AvS/Yr26 & 1 & 2 & 4 & 1 & 5 & 2 & 4 & 3 & 1 & 2 & 3 & 8 & 8 & 0 & 2 \\
\hline $\mathrm{AvS} / Y r 27$ & 7 & 7 & 7 & 7 & 6 & 6 & 7 & 6 & 7 & 5 & 7 & 7 & 7 & 7 & 7 \\
\hline AvS/Yr30 & 7 & 7 & 7 & 7 & 5 & 7 & 7 & 7 & 7 & 6 & 5 & 7 & 7 & 4 & 4 \\
\hline $\mathrm{AvS} / Y r 32$ & 3 & 4 & 6 & 5 & 6 & 2 & 1 & 4 & 1 & 6 & 7 & 7 & 7 & 7 & 3 \\
\hline AvS/YrA & 7 & 7 & 7 & 7 & 7 & 7 & 2 & 7 & 7 & 7 & 7 & 7 & 7 & 7 & 7 \\
\hline $\mathrm{AvS} / Y r S p$ & 4 & 1 & 6 & 2 & 1 & 1 & 7 & 5 & 3 & 6 & 2 & 7 & 7 & 7 & 7 \\
\hline $\mathrm{AvS} / Y r S k$ & 5 & 6 & 7 & 5 & 6 & 7 & 7 & 7 & 3 & 3 & 7 & 8 & 7 & 7 & 7 \\
\hline AvS & 7 & 7 & 7 & 7 & 7 & 7 & 7 & 7 & 7 & 7 & 7 & 7 & 7 & 8 & 8 \\
\hline Mingxian 169 & 7 & 8 & 8 & 8 & 7 & 7 & 7 & 8 & 7 & 8 & 7 & 8 & 8 & 8 & 7 \\
\hline
\end{tabular}

a AvS = Avocet $\mathrm{S}$.

b $0=$ no visible signs or symptoms; 1 = necrotic and/or chlorotic flecks, no sporulation; 2 = necrotic and/or chlorotic blotches or stripes, no sporulation; $3=$ necrotic and/or chlorotic blotches or stripes, trace amounts of sporulation; $4=$ necrotic and/or chlorotic blotches or stripes, light sporulation; $5=$ necrotic and/or chlorotic blotches or stripes, intermediate sporulation; $6=$ necrotic and/or chlorotic blotches or stripes, moderate sporulation; $7=$ necrotic and/or chlorotic blotches or stripes, abundant sporulation; $8=$ chlorosis behind sporulating area, abundant sporulation; and $9=$ no necrosis or chlorosis, abundant sporulation. 
results from races showing high ITs on a cultivar to eliminate $\mathrm{Yr}$ genes from the cultivar; this elimination led to a short list of $Y r$ genes that could exist in the cultivar. The second step of the program was to use the data from races showing low ITs on the cultivar; the output listed the low ITs produced on the cultivar and the isolines with corresponding $\mathrm{Yr}$ genes that were not determined in the first step. The results from the second step were compared visually, from which an $Y r$ gene was determined to be present if the low IT produced on the cultivar by the races matched the low IT on the matching NIL; otherwise, the $Y r$ gene was considered not present. In addition, if the IT of a cultivar was lower than that tested on any of the NILs listed in the second step, then the cultivar was considered to possess an unknown gene that conditions a lower IT that is epistatic to the identified $\mathrm{Yr}$ gene.

\section{Results}

Yr genes in wheat cultivars based on gene postulation and molecular marker tests. At seedling stage, the $Y r$ genes were postulated in the 66 wheat cultivars based on the comparisons of their ITs with those of the $21 \mathrm{Yr}$ NILs. ITs of 20 NILs were segregated when tested with the 15 Pst races (Table 2), indicating the ability to postulate 20 $Y r$ genes: namely, $Y r 1, Y r 3, Y r 4, Y r 5, Y r 6, Y r 7, Y r 8, Y r 9, Y r 10, Y r 15$, Yr17, Yr24, Yr25, Yr26, Yr27, Yr30, Yr32, YrA, YrSp, and YrSk. The results showed that cultivars containing $\operatorname{Yr} 5$ expressed low ITs to all $P s t$ races. Cultivars containing $Y r 15$ had low ITs to $14 P s t$ races except race 70E72. The susceptible check Mingxian 169 and Avocet S conferred high ITs to all 15 Pst races. The molecular marker results showed that 31 cultivars, 12 cultivars, and one cultivar were successfully amplified with primers AF1/4 for $\operatorname{Yr} 9$, SC200 for $\operatorname{Yr} 10$, and We173 for $Y r 26$, respectively, indicating the possible presence of these genes in the respective cultivars. However, no PCR products were generated by primers $Y r 5$-KASP ( $Y r 5)$, csLv34 ( $Y r 18)$, and both KinI and KinII (Yr15), suggesting that these genes are not present in the cultivars studied here.

Four genes $(\mathrm{Yr} 9, \mathrm{Yr} 10, \mathrm{Yr} 26$, and $\mathrm{Yr} 32$ either singly or in combination) were postulated in 24 wheat cultivars. No $\mathrm{Yr}$ genes were finalized or postulated in six cultivars, whereas 36 cultivars might contain an unknown $\mathrm{Yr}$ gene or genes (Table 4). $\mathrm{Yr} 9$ was postulated in 19 cultivars, five of which (Weimai 7, Shanrong 3, Shixin 616, Shijiazhuang 8, and Xiaoyan 22) might contain only $\operatorname{Yr} 9$ because they were susceptible to four $\operatorname{Yr} 9$ virulent races $(127 \mathrm{E} 255,63 \mathrm{E} 254,111 \mathrm{E} 239$, and 111E222) and resistant to all other races, which was consistent with the ITs of $\operatorname{Yr} 9$. Five cultivars (Shannong 664, Xin 2899, Qifeng 1, Henong 6049, and Shixin 618) displayed low ITs consistent with races avirulent to differentials Avocet ${ }^{*} \mathrm{~S} / \mathrm{Yr} 9$ and Avocet*S/Yr32, indicating that they might contain $Y r 9$ and $Y r 32$. Jinmai 1 was resistant to all races avirulent to cultivars containing $Y r 9, Y r 32$, and a race (127E255) that was virulent to those cultivars containing $\operatorname{Yr} 9$ and Yr32, suggesting that it might contain $\operatorname{Yr} 9, \mathrm{Yr} 32$, and an unknown Yr gene(s). Six cultivars (Shannong 23, Kenong 199, Shi 4185, Ji 5265, Zhouheimai 1, and Zhoumai 24) might contain $\operatorname{Yr} 9$ and an unknown $Y r$ gene(s) because cultivars containing $\operatorname{Yr} 9$ were susceptible to 127E255, 63E254, 111E239, and 111E222 but resistant to other races. Cultivars Shannong 23, Kenong 199, Shi 4185, Ji 5265, and Zhouheimai 1 containing $\operatorname{Yr} 9$ showed ITs lower than that of Avocet*S/Yr9 tested with race 66E154; thus, they should contain an unknown $\mathrm{Yr}$ gene(s) in addition to $\mathrm{Yr}$ 9. Zhoumai 24 was susceptible to races 127E255, 63E254, and 111E222 but resistant to $111 \mathrm{E} 222$ and some other races, indicating that this cultivar contains $\operatorname{Yr} 9$ and an unknown $\mathrm{Yr}$ gene(s). Taishan 21 and $\mathrm{Zi} 12$ might contain Yr10 based on their susceptibility to races 114E26, 127E255, and $63 \mathrm{E} 254$ and their resistance to the other 12 races, consistent with the ITs of $Y r 10$. Three cultivars (Langyan 43, Xinong 889, and Yunfeng 139) had low ITs for all races tested but did not have the $\operatorname{Yr} 5$ linked marker. Langyan 43 was postulated to contain $Y r 9$ and an unknown $\mathrm{Yr}$ gene(s), Xinong 889 contained $\mathrm{Yr} 10$ and an unknown $\mathrm{Yr}$ gene(s), and Yunfeng 139 contained $Y r 10, Y r 26$, and an unknown $Y r$ gene(s) according to the molecular marker tested.

Field reactions. According to the field reactions, the 66 cultivars could be classified into three groups based on the characteristics of resistant and moderately resistant or susceptible and moderately susceptible reactions (Table 1). In group 1, 10 cultivars (15.2\%) (Huaimai 16, Langyan 43, Shannong 21, Taishan 21, Taishan 22, Taishan 24, Xinong 889, Yunfeng 139, Zhoumai 24, and Zi 12) were resistant in all field tests. Group 2 consisted of 21 cultivars $(31.8 \%)$ that were resistant to one or two races in the field tests. Group 3 had 35 cultivars $(53 \%)$ that were susceptible in all field tests.

\section{Discussion}

In this study, 66 wheat cultivars that were widely grown in the Huang-Huai-Hai region of China during 2000 to 2016 were postulated for $Y r$ genes based on seedling tests with a series of Pst races and also tested with linked markers for some $Y r$ genes. The results of the molecular tests and gene postulations were consistent for many of the cultivars. However, in some cases, conflicts were observed between the postulated genes and molecular proofs. For example, cultivar 95-111-6-3-10 (line 58) had the target product of the 1BL/1RS molecular marker but no postulated $\operatorname{Yr} 9$ gene (Li et al. 2006).

Table 3. Specific primer sequences for stripe rust resistance genes $\operatorname{Yr} 5, \operatorname{Yr} 9$ (1BL/1RS), $\operatorname{Yr} 10, \operatorname{Yr} 15, \mathrm{Yr} 18$, and $\operatorname{Yr} 26$

\begin{tabular}{|c|c|c|c|c|}
\hline Yr gene & Primer name & Primer sequence $\left(5^{\prime}\right.$ to $\left.3^{\prime}\right)$ & Distance (cM) & PCR program \\
\hline \multirow[t]{2}{*}{$\operatorname{Yr} 5$} & Yr5-KASP & CTCACGCATTTGACCATATACAAC & Cloned & $\begin{array}{l}94^{\circ} \mathrm{C} 5 \mathrm{~min} ; 94^{\circ} \mathrm{C} 30 \mathrm{~s}, 60^{\circ} \mathrm{C} 45 \mathrm{~s} \text {, and } 72^{\circ} \mathrm{C} 45 \mathrm{~s}, 35 \\
\text { cycles; } 72^{\circ} \mathrm{C} 7 \mathrm{~min} ; 4^{\circ} \mathrm{C} \text { continuous }\end{array}$ \\
\hline & & TATTGCATAACATGGCCTCCAGT & & \\
\hline \multirow[t]{2}{*}{$\operatorname{Yr} 9(1 \mathrm{BL} / 1 \mathrm{RS})$} & $\mathrm{AF} 1 / 4$ & GGAGACATCATGAAACATTTG & $\begin{array}{l}\text { Rye chromosome } \\
\text { specific }\end{array}$ & $\begin{array}{l}94^{\circ} \mathrm{C} 3 \mathrm{~min} ; 94^{\circ} \mathrm{C} 60 \mathrm{~s}, 60^{\circ} \mathrm{C} 60 \mathrm{~s} \text {, and } 72^{\circ} \mathrm{C} 90 \mathrm{~s}, 35 \\
\text { cycles; } 72^{\circ} \mathrm{C} 10 \mathrm{~min} ; 4^{\circ} \mathrm{C} \text { continuous }\end{array}$ \\
\hline & & CTGTTGTTGGGCAGAAAG & & \\
\hline \multirow[t]{2}{*}{ Yr10 } & SC200 & CTGCAGAGTGACATCATACA & 0.5 & $\begin{array}{l}94^{\circ} \mathrm{C} 5 \mathrm{~min} ; 94^{\circ} \mathrm{C} 60 \mathrm{~s}, 57^{\circ} \mathrm{C} 60 \mathrm{~s} \text {, and } 72^{\circ} \mathrm{C} 90 \mathrm{~s}, 35 \\
\text { cycles; } 72^{\circ} \mathrm{C} 10 \mathrm{~min} ; 4^{\circ} \mathrm{C} \text { continuous }\end{array}$ \\
\hline & & TCGAACTAGTAGATGCTGGC & & \\
\hline \multirow[t]{4}{*}{$\operatorname{Yr} 15$} & KinI & GGAGATAGAGCACATTACAGAC & Cloned & $\begin{array}{l}94^{\circ} \mathrm{C} 5 \mathrm{~min} ; 94^{\circ} \mathrm{C} 30 \mathrm{~s}, 58^{\circ} \mathrm{C} 60 \mathrm{~s}, 72^{\circ} \mathrm{C} 60 \mathrm{~s} \text {, and } 30 \\
\text { cycles; } 72^{\circ} \mathrm{C} 10 \mathrm{~min} ; 4^{\circ} \mathrm{C} \text { continuous }\end{array}$ \\
\hline & & TTTCGCATCCCACCCTACTG & & \\
\hline & KinII & TGCACGCGGATATTAGGTAGG & & $\begin{array}{l}94^{\circ} \mathrm{C} 5 \mathrm{~min} ; 94^{\circ} \mathrm{C} 30 \mathrm{~s}, 60^{\circ} \mathrm{C} 60 \mathrm{~s} \text {, and } 72^{\circ} \mathrm{C} 60 \mathrm{~s}, 30 \\
\text { cycles; } 72^{\circ} \mathrm{C} 10 \mathrm{~min} ; 4^{\circ} \mathrm{C} \text { continuous }\end{array}$ \\
\hline & & TGATGAAGAGGACCAACGCA & & \\
\hline \multirow[t]{2}{*}{$\operatorname{Yr} 18$} & CsLV34 & GTTGGTTAAGACTGGTGATGG & 0.4 & $\begin{array}{l}95^{\circ} \mathrm{C} 5 \mathrm{~min} ; 95^{\circ} \mathrm{C} 30 \mathrm{~s}, 57^{\circ} \mathrm{C} 30 \mathrm{~s} \text {, and } 72^{\circ} \mathrm{C} 50 \mathrm{~s}, 35 \\
\text { cycles; } 72^{\circ} \mathrm{C} 7 \mathrm{~min} ; 4^{\circ} \mathrm{C} \text { continuous }\end{array}$ \\
\hline & & TGCTTGCTATTGCTGAATAGT & & \\
\hline \multirow[t]{2}{*}{ Yr26 } & We173 & GGGACAAGGGGAGTTGAAGC & 1.4 & $\begin{array}{l}94^{\circ} \mathrm{C} 3 \mathrm{~min} ; 95^{\circ} \mathrm{C} 30 \mathrm{~s}, 60^{\circ} \mathrm{C} 60 \mathrm{~s} \text {, and } 72^{\circ} \mathrm{C} 60 \mathrm{~s}, 35 \\
\text { cycles; } 72^{\circ} \mathrm{C} 10 \mathrm{~min} ; 4^{\circ} \mathrm{C} \text { continuous }\end{array}$ \\
\hline & & GAGAGTTCCAAGCAGAACAC & & \\
\hline
\end{tabular}


Similarly, $\operatorname{Yr} 9$ was postulated in 19 cultivars but the specific molecular marker for the 1RS chromosome was detected in 31 cultivars. Previous studies suggested that many independent genes, such as yield and quality genes, are present on 1RS (Mago et al. 2005). Thus, $\operatorname{Yr} 9$ might have been lost during the yield or quality trait selection although there were positive amplifications in PCR reaction with the chromosome 1RS specific AF1/4 primers. In another case, one new $\mathrm{Yr}$ gene named $\mathrm{YrCn} 17$ located on $1 \mathrm{RS}$ led to the mimetic effects of $Y r 9$ in breeding lines (Ren et al. 2009). Because of the unavoidable crossover between target genes and linked molecular markers, such

Table 4. Seedling infection types in 66 common wheat cultivars from the Huang-Huai-Hai region of China tested with 15 races of Puccinia striiformis f. sp. tritici

\begin{tabular}{|c|c|c|c|c|c|c|c|c|c|c|c|c|c|c|c|c|c|}
\hline \multirow[b]{2}{*}{ Line } & \multirow[b]{2}{*}{ Cultivar } & \multicolumn{15}{|c|}{ Infection type at the seedling stage ${ }^{a}$} & \multirow{2}{*}{$\begin{array}{c}Y r \text { gene } \\
\text { postulated }^{b}\end{array}$} \\
\hline & & $\overline{66 E 74}$ & 98E26 & 66E10 & 66E154 & $86 \mathrm{E} 90$ & 70E72 & 114E26 & 98E90 & $66 \mathrm{E} 26$ & 72E66 & 70E10 & $127 \mathrm{E} 255$ & 63E254 & $111 E 239$ & $111 \mathrm{E} 222$ & \\
\hline 1 & Gaoyou 9618 & 7 & 3 & 4 & 4 & 1 & 0 & 1 & 0 & 1 & 0 & 0 & 7 & 7 & 7 & 7 & + \\
\hline 2 & Han 00-7086 & 0 & 1 & 0 & 7 & 0 & 0 & 0 & 0 & 0 & 0 & 0 & 7 & 7 & 7 & 7 & + \\
\hline 3 & Heng 0628 & 0 & 1 & 0 & 7 & 0 & 0 & 0 & 0 & 1 & 0 & 0 & 7 & 7 & 7 & 7 & + \\
\hline 4 & Heng 6599 & 4 & 3 & 1 & 3 & 3 & 4 & 4 & 3 & 1 & 2 & 2 & 7 & 7 & 7 & 7 & + \\
\hline 5 & Henong 6049 & 5 & 1 & 0 & 6 & 0 & 0 & 0 & 0 & 1 & 4 & 1 & 7 & 8 & 7 & 2 & $Y r 9, Y r 32$ \\
\hline 6 & Henong 827 & 0 & 1 & 1 & 7 & 0 & 0 & 1 & 3 & 3 & 0 & 0 & 7 & 8 & 7 & 3 & + \\
\hline 7 & Huaimai 16 & 7 & 7 & 7 & 7 & 7 & 7 & 7 & 7 & 7 & 7 & 7 & 7 & 7 & 7 & 7 & - \\
\hline 8 & Huaimai 18 & 3 & 1 & 1 & 7 & 0 & 1 & 1 & 0 & 1 & 1 & 1 & 8 & 7 & 7 & 7 & + \\
\hline 9 & Ji 5265 & 0 & 0 & 0 & 1 & 0 & 0 & 0 & 0 & 1 & 0 & 1 & 7 & 7 & 7 & 7 & $Y r 9,+$ \\
\hline 10 & Jifeng 703 & 7 & 1 & 1 & 7 & 3 & 0 & 1 & 0 & 1 & 1 & 1 & 7 & 7 & 5 & 7 & + \\
\hline 11 & Jimai 19 & 7 & 7 & 6 & 6 & 7 & 5 & 0 & 7 & 7 & 1 & 1 & 7 & 7 & 7 & 6 & + \\
\hline 12 & Jimai 21 & 7 & 7 & 5 & 5 & 7 & 6 & 6 & 5 & 6 & 7 & 7 & 7 & 7 & 7 & 7 & + \\
\hline 13 & Jining 16 & 7 & 7 & 7 & 7 & 7 & 7 & 7 & 7 & 7 & 7 & 7 & 7 & 7 & 8 & 7 & - \\
\hline 14 & Jining 17 & 7 & 0 & 7 & 7 & 7 & 0 & 1 & 0 & 0 & 0 & 1 & 8 & 8 & 7 & 7 & + \\
\hline 15 & Jinmai 1 & 6 & 0 & 1 & 6 & 0 & 0 & 0 & 0 & 0 & 0 & 1 & 4 & 7 & 7 & 2 & $Y r 9, Y r 32,+$ \\
\hline 16 & Kenong 199 & 0 & 1 & 0 & 0 & 0 & 0 & 0 & 0 & 0 & 0 & 0 & 7 & 7 & 7 & 7 & $\mathrm{Yr} 9,+$ \\
\hline 17 & Kexin 9 & 7 & 7 & 7 & 7 & 7 & 7 & 7 & 7 & 7 & 7 & 7 & 6 & 7 & 4 & 0 & + \\
\hline 18 & Lai 95021 & 7 & 7 & 7 & 7 & 7 & 7 & 7 & 7 & 7 & 7 & 7 & 7 & 7 & 7 & 6 & + \\
\hline 19 & Langyan 43 & 2 & 0 & 0 & 4 & 0 & 1 & 0 & 0 & 1 & 1 & 0 & 5 & 6 & 2 & 2 & $Y r 9,+$ \\
\hline 20 & Liangxing 99 & 1 & 0 & 1 & 7 & 0 & 5 & 0 & 0 & 1 & 1 & 1 & 7 & 8 & 8 & 7 & + \\
\hline 21 & Linmai 4 & 7 & 7 & 7 & 7 & 7 & 7 & 7 & 7 & 7 & 7 & 7 & 7 & 7 & 7 & 0 & + \\
\hline 22 & Luohan 6 & 7 & 7 & 7 & 7 & 7 & 7 & 7 & 7 & 7 & 7 & 7 & 8 & 7 & 7 & 7 & - \\
\hline 23 & Luohan 8 & 5 & 1 & 0 & 7 & 1 & 1 & 1 & 1 & 1 & 1 & 1 & 7 & 7 & 7 & 7 & + \\
\hline 24 & Qifeng 1 & 1 & 1 & 0 & 4 & 1 & 0 & 0 & 1 & 1 & 0 & 1 & 7 & 7 & 7 & 0 & $Y r 9, Y r 32$ \\
\hline 25 & Qingnong 2 & 1 & 5 & 3 & 5 & 3 & 4 & 3 & 2 & 1 & 1 & 0 & 6 & 7 & 7 & 0 & + \\
\hline 26 & Shannong 12 & 7 & 7 & 7 & 7 & 7 & 7 & 7 & 7 & 7 & 7 & 7 & 8 & 7 & 7 & 7 & - \\
\hline 27 & Shannong 15 & 1 & 1 & 0 & 0 & 0 & 5 & 2 & 2 & 1 & 4 & 7 & 5 & 8 & 8 & 5 & + \\
\hline 28 & Shannong 17 & 7 & 7 & 7 & 7 & 7 & 7 & 7 & 7 & 7 & 7 & 7 & 7 & 7 & 7 & 7 & - \\
\hline 29 & Shannong 18 & 3 & 2 & 3 & 4 & 4 & 6 & 3 & 2 & 4 & 4 & 5 & 4 & 7 & 7 & 4 & + \\
\hline 30 & Shannong 21 & 0 & 0 & 1 & 7 & 0 & 2 & 0 & 1 & 1 & 1 & 1 & 7 & 7 & 7 & 0 & + \\
\hline 31 & Shannong 23 & 0 & 1 & 1 & 0 & 1 & 0 & 0 & 0 & 6 & 0 & 0 & 7 & 8 & 7 & 7 & $Y r 9,+$ \\
\hline 32 & Shannong 29 & 5 & 0 & 0 & 7 & 0 & 6 & 0 & 1 & 0 & 5 & 1 & 7 & 0 & 7 & 3 & + \\
\hline 33 & Shannong 664 & 0 & 1 & 1 & 0 & 0 & 1 & 0 & 4 & 1 & 1 & 1 & 7 & 7 & 7 & 4 & $Y r 9, Y r 32$ \\
\hline 34 & Shannongzimai 1 & 5 & 6 & 5 & 5 & 5 & 3 & 3 & 5 & 6 & 5 & 7 & 6 & 7 & 7 & 7 & + \\
\hline 35 & Shanrong 3 & 1 & 1 & 1 & 5 & 0 & 1 & 1 & 1 & 1 & 1 & 0 & 8 & 7 & 7 & 7 & $Y r 9$ \\
\hline 36 & Shi 4185 & 0 & 1 & 1 & 1 & 0 & 0 & 0 & 0 & 0 & 0 & 1 & 7 & 8 & 7 & 7 & $Y r 9,+$ \\
\hline 37 & Shijiazhuang 8 & 0 & 0 & 0 & 6 & 0 & 3 & 2 & 0 & 0 & 0 & 0 & 7 & 7 & 7 & 7 & $\mathrm{Yr} 9$ \\
\hline 38 & Shimai 15 & 0 & 0 & 0 & 6 & 0 & 0 & 0 & 1 & 1 & 0 & 0 & 7 & 7 & 0 & 2 & $Y r 9,+$ \\
\hline 39 & Shimai 16 & 0 & 1 & 1 & 7 & 0 & 0 & 2 & 0 & 0 & 4 & 1 & 7 & 7 & 5 & 7 & + \\
\hline 40 & Shimai 18 & 0 & 1 & 1 & 7 & 0 & 0 & 0 & 0 & 0 & 0 & 0 & 8 & 8 & 7 & 7 & + \\
\hline 41 & Shixin 616 & 6 & 1 & 0 & 6 & 1 & 3 & 2 & 1 & 1 & 1 & 0 & 7 & 8 & 7 & 7 & $\operatorname{Yr} 9$ \\
\hline 42 & Shixin 618 & 6 & 1 & 1 & 0 & 1 & 0 & 1 & 3 & 1 & 3 & 0 & 7 & 7 & 7 & 2 & $Y r 9, Y r 32$ \\
\hline 43 & Shixin 828 & 3 & 1 & 1 & 7 & 0 & 7 & 1 & 7 & 0 & 7 & 0 & 7 & 7 & 2 & 2 & + \\
\hline 44 & Shiyou 17 & 7 & 5 & 6 & 4 & 6 & 6 & 7 & 6 & 4 & 5 & 7 & 7 & 7 & 7 & 7 & + \\
\hline 45 & Taishan 21 & 1 & 1 & 1 & 3 & 1 & 3 & 7 & 1 & 1 & 1 & 1 & 7 & 7 & 5 & 3 & Yrlo \\
\hline 46 & Taishan 22 & 7 & 7 & 7 & 7 & 7 & 7 & 7 & 7 & 7 & 7 & 7 & 5 & 7 & 7 & 2 & + \\
\hline 47 & Taishan 24 & 7 & 7 & 7 & 7 & 7 & 7 & 6 & 7 & 7 & 7 & 7 & 7 & 7 & 7 & 0 & + \\
\hline 48 & Tanmai 98 & 0 & 1 & 0 & 3 & 1 & 3 & 1 & 7 & 1 & 1 & 7 & 7 & 7 & 5 & 5 & + \\
\hline 49 & Weimai 7 & 0 & 1 & 1 & 5 & 1 & 1 & 0 & 0 & 2 & 1 & 1 & 7 & 7 & 7 & 7 & $\operatorname{Yr} 9$ \\
\hline 50 & Weimai 8 & 0 & 0 & 1 & 7 & 5 & 0 & 1 & 1 & 1 & 1 & 1 & 7 & 7 & 5 & 4 & + \\
\hline 51 & Wennong 5 & 0 & 3 & 1 & 2 & 6 & 6 & 2 & 6 & 1 & 2 & 1 & 7 & 7 & 7 & 4 & + \\
\hline 52 & Wennong 6 & 7 & 7 & 7 & 6 & 7 & 7 & 7 & 6 & 6 & 7 & 7 & 7 & 7 & 8 & 7 & + \\
\hline 53 & Xiaoyan 22 & 1 & 1 & 0 & 1 & 1 & 3 & 1 & 0 & 1 & 0 & 1 & 8 & 7 & 7 & 7 & $\operatorname{Yr} 9$ \\
\hline 54 & Xiaoyan 81 & 7 & 7 & 7 & 7 & 7 & 7 & 7 & 7 & 7 & 7 & 7 & 7 & 7 & 7 & 4 & + \\
\hline 55 & Xin 2899 & 0 & 1 & 0 & 5 & 3 & 1 & 0 & 0 & 1 & 0 & 0 & 7 & 7 & 7 & 0 & $Y r 9, Y r 32$ \\
\hline 56 & Xinong 889 & 1 & 3 & 1 & 3 & 1 & 1 & 1 & 2 & 1 & 1 & 1 & 1 & 3 & 4 & 2 & $\mathrm{YrlO},+$ \\
\hline 57 & Yan 99102 & 6 & 2 & 1 & 7 & 1 & 0 & 0 & 1 & 3 & 0 & 1 & 7 & 7 & 8 & 7 & + \\
\hline 58 & Yannong 0428 & 3 & 3 & 7 & 7 & 3 & 6 & 2 & 3 & 3 & 0 & 5 & 7 & 7 & 7 & 0 & + \\
\hline 59 & Yannong 19 & 7 & 7 & 7 & 7 & 7 & 7 & 7 & 7 & 7 & 7 & 7 & 7 & 7 & 7 & 0 & + \\
\hline 60 & Yannong 21 & 7 & 7 & 7 & 7 & 7 & 7 & 7 & 7 & 7 & 7 & 7 & 8 & 8 & 7 & 7 & - \\
\hline 61 & Yannong 22 & 0 & 1 & 0 & 7 & 0 & 1 & 1 & 0 & 1 & 0 & 1 & 7 & 7 & 7 & 3 & + \\
\hline 62 & Yannong 836 & 6 & 6 & 4 & 5 & 6 & 1 & 3 & 6 & 3 & 5 & 7 & 7 & 7 & 7 & 0 & Yr32 \\
\hline 63 & Yunfeng 139 & 1 & 1 & 1 & 1 & 1 & 2 & 1 & 1 & 1 & 1 & 1 & 2 & 6 & 2 & 5 & $\begin{array}{c}Y r 10, Y r 26 \\
+\end{array}$ \\
\hline 64 & Zhouheimai 1 & 1 & 1 & 0 & 2 & 1 & 0 & 1 & 0 & 1 & 1 & 0 & 8 & 7 & 7 & 8 & $Y r 9,+$ \\
\hline 65 & Zhoumai 24 & 1 & 1 & 0 & 1 & 0 & 0 & 2 & 1 & 1 & 1 & 1 & 7 & 7 & 0 & 7 & $Y r 9,+$ \\
\hline 66 & Zi 12 & 1 & 2 & 1 & 1 & 1 & 1 & 7 & 1 & 3 & 2 & 2 & 7 & 7 & 5 & 0 & Yrlo \\
\hline
\end{tabular}

a $0=$ no visible signs or symptoms; $1=$ necrotic and/or chlorotic flecks, no sporulation; $2=$ necrotic and/or chlorotic blotches or stripes, no sporulation; $3=$ necrotic and/or chlorotic blotches or stripes, trace amounts of sporulation; $4=$ necrotic and/or chlorotic blotches or stripes, light sporulation; $5=$ necrotic and/or chlorotic blotches or stripes, intermediate sporulation; $6=$ necrotic and/or chlorotic blotches or stripes, moderate sporulation; $7=$ necrotic and/or chlorotic blotches or stripes, abundant sporulation; $8=$ chlorosis behind sporulating area, abundant sporulation; and $9=$ no necrosis or chlorosis, abundant sporulation. b A plus sign indicates an unknown $Y r$ gene, whereas a minus sign indicates that no $Y r$ gene was postulated. 
conflicts may occur when linked markers are used in nonsegregated populations (Wu et al. 2007). This is a very complicated process, and scientists need to make additional efforts to identify the mechanisms. To improve the reliability of the results, only the results consistent between the molecular marker tests and gene postulations are presented in our research.

For example, no PCR product was generated by primer We173 ( $Y r 26)$ for Shimai 15, although Shimai 15 showed the same seedling resistance spectrum as Avocet S/Yr26 and 92R173 (Yr26) was in the pedigree of this cultivar. Thus, our results suggestthat Shimai 15 did not contain $Y r 26$, which was consistent with the results of Zhang et al. (2014). Xu et al. (2011) reported that Taishan 21 and $\mathrm{Zi} 12$ did not contain $\mathrm{Yr} 10$, but our results showed that these cultivars might have $\mathrm{YrlO}$ because the target fragments were successfully amplified and the cultivars showed consistent ITs with Avocet S/Yr10. Zi12 might have Yr10 inherited from the Guinong lines because Guinong 35-2 was in the pedigree of this cultivar. In addition, Marchal et al. (2018) and Klymiuk et al. (2018) developed molecular markers $\operatorname{Yr} 5$-KASP for $Y r 5$ and KinI and KinII for $\operatorname{Yr} 15$ based on the target gene sequences, respectively. Li et al. (2008) reported that Yunfeng 139 (also known as Shaanmai 139) carried $\operatorname{Yr} 5$, Yr10, Yr15, and Yr26. However, our results showed that Yunfeng 139 might carry $\mathrm{Yr} 10, \mathrm{Yr} 26$, and unknown $\mathrm{Yr}$ genes. Yunfeng 139 does not have $Y r 5$ or $Y r 15$ because no PCR products were generated using primers $\operatorname{Yr} 5$-KASP or KinI and KinII, even though Yunfeng 139 showed resistance to all 15 Pst races. Zhang et al. (2016) reported that Yunfeng 139, which exhibited resistance to the majority of Pst isolates, possessed an unknown $Y r$ gene located on the 1B chromosome that was different from $\operatorname{Yr} 5, Y 10, Y r 15$, and Yr26. Although T. turgidum var. dicoccoides was in the pedigree of Yunfeng 139, the cultivar does not necessarily have $\operatorname{Yr} 15$, because either the T. turgidum var. dicoccoides line may not have $Y r 15$ or Yr15 may have been lost during selection. The introgression of a target gene from a wild wheat is complicated as a result of several backcrossing and selection steps that were needed to reduce linkage drags (Yaniv et al. 2015). Similar results were observed for Langyan 43 and Xinnong 889.

Of all postulated genes, $\operatorname{Yr} 9$ from the translocation of $1 \mathrm{BL} / 1 \mathrm{RS}$ containing resistance to other diseases, yield, and quality traits is widely used in breeding programs all over the world (Wieser et al. 2000). In the early 1970s, 1BL/1RS lines such as Avorora, Lovrin 10, Lovrin 13, Predgornaya 2, Kavkaz, and Neuzucht were introduced in China and intensively used in Chinese wheat breeding programs (He et al. 2001), which caused a high frequency of $\operatorname{Yr} 9$ (Gebrewahid et al. 2017; Ren et al. 2015). Our results showed that $19(28.8 \%)$ of 66 cultivars carried $\mathrm{Yr} 9$. According to the pedigree, the presence of $\operatorname{Yr} 9$ in Xin 2899 might be from Lovrin 13. $\operatorname{Yr} 9$ in Jinmai 1, Xiaoyan 22, and Shannong 664 might be from Lovrin 13 and/ or Lumai 14 (Ge et al. 2009) because these two cultivars carry $\operatorname{Yr} 9$ (Niu et al. 2000). Cultivars Shi 4185, Ji 5265, and Langyan 43 most likely inherited the $\operatorname{Yr} 9$ gene from Lovrin 10 . Henong 6049, Shimai 15 , and Shijiazhuang 8 carry $\operatorname{Yr} 9$, possibly from Lovrin 10 and/or Avorora because these $\mathrm{Yr} 9$ donors were present in the pedigree of these Chinese cultivars (Huang et al. 2017). The presence of $\operatorname{Yr} 9$ in Zhouheimai 1 and Zhoumai 24 might be from Predgornaya 2 and/ or Neuzucht because the two Chinese cultivars have these $\operatorname{Yr} 9$ varieties in their pedigrees. Ren et al. (2015) reported that Jimai 21 contained $L r 26$ based on the $L r 26 \mathrm{~F} / \mathrm{R}: \mathrm{IB}-267$ molecular marker test and gene postulation. However, our results demonstrated that Jimai 21 did not possess $\operatorname{Yr} 9$ because 66E74, 98E26, 86E90, 72E66, and $70 \mathrm{E} 10$ were virulent to Jimai 21 but avirulent to Avocet S/Yr9. In addition, no PCR products were successfully amplified by primer AF1/ 4 in Jimai 21. Moreover, the 1BL/1RS lines are not present in the Jimai 21 pedigree. Yannong 19 and Yannong 21 have the same pedigree but show different ITs to 111E222 (Yannong 19 was resistant to race 111E222 [IT $=0$ ], whereas Yannong 21 was susceptible [IT $\geq$ 7]), suggesting that phenotypic selection played a critical role in breeding (Niu et al. 2000).

In the early 2000s, the utilization and development of wheat stripe rust APR was increasingly popular in breeding programs in China
(He et al. 2006), but efforts made by Chinese breeders were slightly less than those in other countries (He et al. 2011). In our study, only 10 wheat cultivars showed resistance to all races (CYR32, CYR33, and CYR34) at the adult-plant stage in the field and no cultivars contained the $\operatorname{Yr} 18$ gene, which is an APR gene widely used in breeding programs in many parts of the world. Thus, the wheat cultivars widely grown in the Huang-Huai-Hai region in recent years still have a low level of APR against stripe rust. Inheritance studies conducted by scientists from the International Maize and Wheat Improvement Center showed that combinations of three to five APR genes resulted in a high level of resistance, although individual nonhypersensitive-type genes had little resistance to Pst (Singh et al. 2000). The Huang-Huai-Hai region is thought to have spring epidemics of stripe rust, and planting cultivars with APR in this region is the first option and a vital strategy for controlling stripe rust. Therefore, employing APR genes such as $\operatorname{Yr} 36$ (Chhuneja et al. 2008) and Yr52 (Ren et al. 2012), especially APR gene clusters such as $\mathrm{Yr} 18 /$ Lr34/Pm38 (Lillemo et al. 2008), Yr29/Lr46/Pm39 (Lillemo et al. 2008), and Yr46/Lr67(Herrera-Foessel et al. 2011), would be needed in resistance pyramiding programs for developing resistant cultivars to control stripe rust.

\section{Acknowledgments}

We thank the anonymous reviewers for contributing to the improvement of the manuscript and Prof. Mogens Støvring Hovmøller for kindly supplying the DK and UK races of Pst.

\section{Literature Cited}

Bai, B. B., Liu, T. G., Liu, B., Gao, L., and Chen, W. Q. 2018. High relative parasitic fitness of $\mathrm{G} 22$ derivatives is associated with the epidemic potential of wheat stripe rust in China. Plant Dis. 102:483-487.

Bai, Y. L., Zhang, Z. Y., Xu, S. C., and Lin, F. 2010. Advances in gene postulation in the wheat rust. Plant Prot. 36:36-38.

Chen, W. Q., Liu, T. G., Chen, J. L., and Xu, S. C. 2007. Rules for resistance evaluation of wheat to diseases and insect pests. Part 1: Rule for resistance evaluation of wheat to yellow rust (Puccinia striiformis West. f. sp. tritici Eriks. et Henn.): NT/T1443.1-2007. 2007-09-14[2017-03-03]. China Agriculture Press Co., Ltd., Beijing, China.

Chen, W. Q., Wellings, C., Chen, X. M., Kang, Z. S., and Liu, T. G. 2014. Wheat stripe (yellow) rust caused by Puccinia striiformis f. sp. tritici. Mol. Plant Pathol. 15:433-446.

Chen, W. Q., Wu, L. R., Liu, T. G., Xu, S. C., Jin, S. L., Peng, Y. L., and Wang, B. T. 2009. Race dynamics, diversity, and virulence evolution in Puccinia striiformis $\mathrm{f}$. sp. tritici, the causal agent of wheat stripe rust in China from 2003 to 2007. Plant Dis. 93:1093-1101.

Chen, X. M. 2005. Epidemiology and control of stripe rust [Puccinia striiformis $\mathrm{f}$ sp. tritici] on wheat. Can. J. Plant Pathol. 27:314-337.

Chhuneja, P., Kaur, S., Garg, T., Ghai, M., Kaur, S., Prashar, M., Bains, N. S., Goel, R. K., Keller, B., and Dhaliwal, H. S. 2008. Mapping of adult plant stripe rust resistance genes in diploid A genome wheat species and their transfer to bread wheat. Theor. Appl. Genet. 116:313-324.

Dubin, H. J., Johnson, R., and Stubbs, R. W. 1989. Postulated genes for resistance to stripe rust in selected CIMMYT and related wheats. Plant Dis. 73:472-475

Feng, J., Wang, M., See, D. R., Chao, S., Zheng, Y. L., and Chen, X. 2018 Characterization of novel gene $Y r 79$ and four additional QTL for all-stage and high-temperature adult-plant resistance to stripe rust in spring wheat PI 182103. Phytopathology 108:737-747.

Feng, J., Zhang, Z. Y., Lin, R., and Xu, S. C. 2009. Postulation of seedling resistance genes in 20 wheat cultivars to yellow rust (Puccinia striiformis $\mathrm{f}$. sp. tritici). J. Integr. Agric. 8:1429-1439.

Flor, H. H. 1971. Current status of the gene-for-gene concept. Annu. Rev Phytopathol. 9:275-296.

Francis, H. A., Leitch, A. R., and Koebner, R. M. D. 1995. Conversion of a RAPDgenerated PCR product, containing a novel dispersed repetitive element, into a fast and robust assay for the presence of rye chromatin in wheat. Theor. Appl. Genet. 90:636-642.

Ge, H. M., Wang, L. F., You, G. X., Hao, C. Y., Dong, Y. C., and Zhang, X. Y 2009. Fundamental roles of cornerstone breeding lines in wheat reflected by SSR random scanning. Sci. Agric. Sin. 42:1503-1511.

Gebrewahid, T. W., Yao, Z. J., Yan, X. C., Gao, P., and Li, Z. F. 2017 Identification of leaf rust resistance genes in Chinese common wheat cultivars. Plant Dis. 101:1729-1737.

Gessese, M., Bariana, H., Wong, D., Hayden, M., and Bansal, U. 2019. Molecular mapping of stripe rust resistance gene in a common wheat landrace Aus 27430 Plant Dis. 103:1166-1171.

He, Z., Lan, C., Chen, X., Zou, Y., Zhuang, Q., and Xia, X. 2011. Progress and perspective in research of adult-plant resistance to stripe rust and powdery mildew in wheat. Sci. Agric. Sin. 44:2193-2215.

He, Z. H., Rajaram, S., Xin, Z. Y., and Huang, G. Z. 2001. A history of wheat breeding in China. J. Comp. Neurol. 523:805-813. 
He, Z. H., Xia, X. C., Luo, J., Xin, Z. Y., Kong, X. Y., Jing, R. L., Wu, Z. L., and Li, X. P. 2006. Trend analysis of international wheat breeding. J. Trit. Crops. 26:154-156.

Herrera-Foessel, S. A., Lagudah, E. S., Huertaespino, J., Hayden, M. J., Bariana, H. S., Singh, D., and Singh, R. P. 2011. New slow-rusting leaf rust and stripe rust resistance genes $\operatorname{Lr67}$ and $Y r 46$ in wheat are pleiotropic or closely linked. Theor. Appl. Genet. 122:239-249.

Hovmøller, M. S. 2007. Sources of seedling and adult plant resistance to Puccinia striiformis f. sp. tritici in European wheats. Plant Breed. 126:225-233.

Huang, L., Liu, T. G., Xiao, X. Z., Qu, C. Y., Liu, B., Gao, L., Luo, P. G., and Chen, W. Q. 2017. Evaluation of stripe rust resistance and molecular detection of $\mathrm{Yr}$ genes of 79 wheat varieties (lines) in China. Sci. Agric. Sin. 50:3122-3134.

Johnson, R., and Taylor, A. J. 1972. Isolates of Puccinia striiformis collected in England from the wheat varieties Maris Beacon and Joss Cambier. Nature 238:105-106.

Klymiuk, V., Yaniv, E., Huang, L., Raats, D., Fatiukha, A., Chen, S., Feng, L., Frenkel, Z., Krugman, T., Lidzbarsky, G., Chang, W., Jaaskelainen, M. J., Schudoma, C., Paulin, L., Laine, P., Bariana, H., Sela, H., Saleem, K., Sorensen, C. K., Hovmoller, M. S., Distelfeld, A., Chalhoub, B., Dubcovsky, J., Korol, A. B., Schulman, A. H., and Fahima, T. 2018. Cloning of the wheat $\mathrm{Yr} 15$ resistance gene sheds light on the plant tandem kinasepseudokinase family. Nat. Commun. 9:3735.

Lagudah, E. S., McFadden, H., Singh, R. P., Huerta-Espino, J., Bariana, H. S., and Spielmeyer, W. 2006. Molecular genetic characterization of the Lr34/Yr18 slow rusting resistance gene region in wheat. Theor. Appl. Genet. 114:21-30.

Li, F. Q., Han, D. J., Wei, G. R., Zeng, Q. D., Huang, L. L., and Kang, Z. S. 2008. Molecular detection of stripe rust resistant genes in 126 winter wheat varieties from the Huanghuai wheat region. Sci. Agric. Sin. 41:3060-3069.

Li, Q., Li, G. B., Yue, W. Y., Du, J. Y., Yang, L. Y., Kang, Z. S., Jing, J. X., and Wang, B. T. 2016. Pathogenicity changes of wheat stripe rust fungus and disease resistance of wheat cultivars (lines) in Shaanxi province during 20022014. Acta Phytopathol. Sin. 46:374-383.

Li, Z. F., Xia, X. C., Zhou, X. C., Niu, Y. C., He, Z. H., Zhang, Y., Li, G. Q., Wan, A. M., Wang, D. S., Chen, X. M., Lu, Q. L., and Singh, R. P. 2006. Seedling and slow rusting resistance to stripe rust in Chinese common wheats. Plant Dis. 90:1302-1312.

Lillemo, M., Asalf, B., Singh, R. P., Huerta-Espino, J., Chen, X. M., He, Z. H., and Bjørnstad, A. 2008. The adult plant rust resistance loci $L r 34 / Y r 18$ and $L r 46 /$ Yr29 are important determinants of partial resistance to powdery mildew in bread wheat line Saar. Theor. Appl. Genet. 116:1155-1166.

Line, R. F., and Qayoum, A. 1992. Virulence, aggressiveness, evolution and distribution of races of Puccinia striiformis (the cause of stripe rust of wheat) in North America, 1968-87. USDA Technical Bulletin No. 1788. National Technical Information Service, Springfield, VA.

Liu, B., Liu, T. G., Zhang, Z. Y., Jia, Q., Wang, B. T., Gao, L., Peng, Y. L., Jin, S. L., and Chen, W. Q. 2017. Discovery and pathogenicity of CYR34, a new race of Puccinia striiformis f. sp. tritici in China. Acta Phytopathol. Sin. 47:682-688.

Liu, T. G., Peng, Y. L., Chen, W. Q., and Zhang, Z. Y. 2010. First detection of virulence in Puccinia striiformis f. sp. tritici in China to resistance genes Yr24 (=Yr26) present in wheat cultivar Chuanmai 42. Plant Dis. 94:1163.

Liu, T. G., Wang, B. T., Jia, Q. Z., Zhang, Z. Y., Li, Q., Cao, S. Q., Peng, Y. L., Jin, S. L., Li, M. J., Liu, B., Cao, L., Xu, X. P., and Chen, W. Q. 2012. Physiologic specialization of Puccinia striiformis f. sp. tritici in China during 2010-2011. J. Trit. Crops. 32:574-578

Liu, T. G., Zhang, Z. Y., Liu, B., Li, G., Peng, Y. L., and Chen, W. Q. 2015. Detection of virulence to $Y r 26$ and pathogenicity to Chinese commercial winter wheat cultivars at seedling stage. Acta Phytopathol. Sin. 45:41-47.

Ma, Z. H. 2018. Researches and control of wheat stripe rust in China. J. Plant Prot. 45:1-6.

Mago, R., Miah, H., Lawrence, G. J., Wellings, C. R., Spielmeyer, W., Bariana, H. S., McIntosh, R. A., Pryor, A. J., and Ellis, J. G. 2005. High-resolution mapping and mutation analysis separate the rust resistance genes $\operatorname{Sr} 31, \operatorname{Lr} 26$ and $\operatorname{Yr} 9$ on the short arm of rye chromosome 1. Theor. Appl. Genet. 112:41-50.

Marchal, C., Zhang, J. P., Zhang, P., Fenwick, P., Steuernagel, B., Adamski, N. M., Boyd, L., McIntosh, R., Wulff, B. B. H., Berry, S., Lagudah, E., and Uauy, C. 2018. BED-domain-containing immune receptors confer diverse resistance spectra to yellow rust. Nat. Plants 4:662-668.
McIntosh, R. A., Dubcovsky, J., Rogers, W. J., Morris, C., and Xia, X. C. 2017. Catalogue of gene symbols for wheat: 2017 supplement. https://shigen.nig.ac.jp/ wheat/komugi/genes/macgene/supplement2017.pdf

Niu, Y. C., Qiao, Q., and Wu, L. R. 2000. Postulation of resistance genes to stripe rust in commercial wheat cultivars from Henan, Shandong and Anhui provinces. Acta Phytopathol. Sin. 7:183-188.

Nsabiyera, V., Bariana, H. S., Qureshi, N., Wong, D., Hayden, M. J., and Bansal, U. K. 2018. Characterisation and mapping of adult plant stripe rust resistance in wheat accession Aus27284. Theor. Appl. Genet. 131:1459-1467.

Pakeerathan, K., Bariana, H., Qureshi, N., Wong, D., Hayden, M., and Bansal, U. 2019. Identification of a new source of stripe rust resistance Yr82 in wheat Theor. Appl. Genet. 132:3169-3176.

Ren, R. S., Wang, M. N., Chen, X. M., and Zhang, Z. J. 2012. Characterization and molecular mapping of $\mathrm{Yr} 52$ for high-temperature adult-plant resistance to stripe rust in spring wheat germplasm PI 183527. Theor. Appl. Genet. 125:847-857.

Ren, T. H., Yang, Z. J., Yan, B. J., Zhang, H. Q., Fu, S. L., and Ren, Z. L. 2009. Development and characterization of a new 1BL.1RS translocation line with resistance to stripe rust and powdery mildew of wheat. Euphytica 169:207-213.

Ren, X. L., Liu, T. G., Liu, B., Gao, L., and Chen, W. Q. 2015. Postulation of seedling leaf rust resistance genes in 84 Chinese winter wheat cultivars. J. Integr. Agric. 14:1992-2001.

Shao, Y. T., Niu, Y. C., Zhu, L. H., Zhai, W. W., Xu, S. C., and Wu, L. R. 2001. Identification of an AFLP marker linked to the stripe rust resistance gene $\mathrm{YrlO}$ in wheat. Chin. Sci. Bull. 46:1466-1468.

Singh, R. P., Huerta-Espino, J., and Rajaram, S. 2000. Achieving near-immunity to leaf and stripe rusts in wheat by combining slow rusting resistance genes. Acta Phytopathol. Entomol. Hung. 35:133-139.

Tang, H. J., and Li, Z. M. 2012. Study on per capita grain demand based on Chinese reasonable dietary pattern. Sci. Agric. Sin. 45:2315-2327.

Wamishe, Y. A., and Milus, E. A. 2004. Seedling resistance genes to leaf rust in soft red winter wheat. Plant Dis. 88:136-146.

Wamishe, Y. A., Thompson, K. C., and Milus, E. A. 2004. A computer program to improve the efficiency and accuracy of postulating race-specific resistance genes. Plant Dis. 88:545-549.

Wan, A. M., Chen, X. M., and He, Z. H. 2007. Wheat stripe rust in China. Aust. J. Agric. Res. 58:605-619.

Wang, C. M., Zhang, Y. P., Han, D. J., Kang, Z. S., Li, G. P., Cao, A. Z., and Chen, P. D. 2008. SSR and STS markers for wheat stripe rust resistance gene $\mathrm{Yr} 26$. Euphytica 159:359-366

Wang, Q., Ma, J. J., Yang, L. J., Li, Q., and Wang, B. T. 2017. Population structure and diversity analysis of Puccinia striiformis f. sp. tritici in Hubei province in 2015. J. Trit. Crops. 37:275-280.

Wellings, C. R. 2011. Global status of stripe rust: A review of historical and current threats. Euphytica 179:129-141.

Wieser, H., Kieffer, R., and Lelley, T. 2000. The influence of 1B/1R chromosome translocation on gluten protein composition and technological properties of bread wheat. J. Sci. Food Agric. 80:1640-1647.

Wu, L., Tan, J., Zhu, Z. H., Wang, Z. L., and Pu, X. R. 2007. Detection of stripe rust resistant genes of $\mathrm{Yr} 5, \mathrm{YrlO}$ and $\mathrm{Yr} 15$ in some Sichuan wheat lines by molecular markers. Southwest China J. Agric. Sci. 20:316-320.

Xu, X. D., Feng, J., Lin, R. M., Hussain, K., Xu, S. C., and Lin, F. 2011 Postulation of stripe rust resistance genes in 44 Chinese wheat cultivars. Int. J. Agric. Biol. 13:665-670.

Yaniv, E., Raats, D., Ronin, Y., Korol, A. B., Grama, A., Bariana, H., Dubcovsky, J., Schulman, A. H., and Fahima, T. 2015. Evaluation of marker-assisted selection for the stripe rust resistance gene $\operatorname{Yr} 15$, introgressed from wild emmer wheat. Mol. Breeding 35:43.

Zhang, H., Zhang, L., Wang, C. Y., Wang, Y. J., Zhou, X. L., Lv, S. K., Liu, X. L., Kang, Z. S., and Ji, W. Q. 2016. Molecular mapping and marker development for the Triticum dicoccoides-derived stripe rust resistance gene YrSM139-1B in bread wheat cv. Shaanmai 139. Theor. Appl. Genet. 129:369-376.

Zhang, Y. W., Liu, T. G., Liu, B., Gao, L., and Chen, W. Q. 2014. Gene postulation of stripe rust resistance genes of 75 Chinese commercial wheat cultivars. Acta Phytophylac. Sin. 41:45-53. 